\title{
The effect of Yucca schidigera liquid extract on water quality and survival of Pacific Red Snapper Lutjanus peru during acclimatization
}

\author{
El efecto del extracto líquido de Yucca schidigera sobre la calidad del agua y supervivencia \\ del pargo rojo del Pacífico Lutjanus peru durante la aclimatación
}

\author{
S Castillo-Vargasmachuca ${ }^{a}$, JT Ponce-Palafox ${ }^{a^{*}}$, JL Arredondo-Figueroa ${ }^{b}$, M García-Ulloa ${ }^{a}$, \\ A Benítez-Valle ${ }^{\mathrm{a}}$, L Martínez-Cárdenas ${ }^{\mathrm{a}}$, D Puga-López ${ }^{\mathrm{c}}$, A Seidavi ${ }^{\mathrm{d}}$ \\ aUniversidad Autónoma de Nayarit, Escuela Nacional de Ingeniería Pesquera, \\ Laboratorio de Bioingeniería Costera, Centro Multidisciplinario de Bahía Banderas, Nayarit, México. \\ bUniversidad Autónoma de Aguascalientes, Centro de Ciencias Agropecuarias, Posta Zootécnica, \\ Jesús María, Aguascalientes, México. \\ 'INP, Centro Regional de Investigación Pesquera de Bahía Banderas Nayarit, \\ Cruz de Huanacaxtle, Bahía de Banderas, Nayarit, México. \\ ${ }^{\mathrm{d} A n i m a l}$ Science Department, Rasht Branch, Islamic Azad University, Rasht, Iran.
}

\begin{abstract}
RESUMEN
El objetivo de este estudio fue determinar el efecto del extracto líquido de $Y$. schidigera sobre la calidad del agua y prevención de la mortalidad del pargo rojo del Pacífico L. Peru, durante la transferencia del medio silvestre a condiciones del laboratorio. Se utilizaron tres tratamientos: extracto líquido concentrado $100 \%$ de $Y$. schidigera natural fue administrado en baja concentración $\left(0,25 \mathrm{mg} \mathrm{L}^{-1}\right)$ y alta concentración $\left(0,75 \mathrm{mg} \mathrm{L}^{-1}\right)$, además de un grupo control sin extracto. El extracto líquido fue administrado cada $72 \mathrm{~h}$ durante 28 días. Se encontró que el extracto $Y$. schidigera reduce la concentración de amonio producto de la excreción de los juveniles y la mortalidad del huachinango durante la aclimatación en un sistema de recirculación. Se recomienda el uso del extracto de yuca en una concentración de $0,75 \mathrm{mg} \mathrm{L}^{-1}$ para reducir el amonio y para una densidad máxima de $10,9 \mathrm{~kg} \mathrm{~m}^{-3}$ y con aireación.
\end{abstract}

Palabras clave: Yucca schidigera, reducción de amonio, pargo, supervivencia.

\section{SUMMARY}

The goal of this study was to determine the effect of the liquid extract of Yucca schidigera on water quality and survival of Pacific red snapper Lutjanus peru during its transfer from wild to laboratory conditions. Three experimental groups $(0.00 ; 0.25$ and $0.75 \mathrm{mg}$ of $Y$. schidigera liquid extract per liter of culture) were tested with four replicates using water recirculating systems. The liquid extract was dispensed every $72 \mathrm{~h}$ during 28 days. It was proved that $Y$. schidigera extract could be effective to reduce ammonia nitrogen caused by biogenic source (excretion of fish juveniles) diminishing mortality of Pacific red snapper during acclimatization process. It is recommended the use of yucca extract concentration at a dose of $0.75 \mathrm{mg} \mathrm{L}^{-1}$ to reduce ammonia concentration in marine water for holding red snapper juveniles.

Key words: Yucca schidigera, ammonia reduction, red snapper, survival.

\section{INTRODUCTION}

According to the latest aquaculture statistics, the total catch of Lutjanidae fish in the Pacific, Atlantic and Caribbean Sea in Mexico, reached more than six thousand metric tons, with an economical value estimated in 46 million USD (CONAPESCA 2012), but due to their high economical value at sizes that ranged from 125 to 350 $\mathrm{g}$, wild stocks are now under a high fisheries pressures (Diaz-Uribe et al 2004). There are some reports focused to look for strategies in increasing the production levels,

Accepted: 03.07.2014.

* Cda. de la Cultura Amado Nervo s/n col. Menchaca C.P. 63155 Tepic, Nayarit, México; jesus.ponce@ usa.net such as the use of floating sea-cages for growing them up, but utilising wild juvenile populations that are captured in specific areas along the Coastal Pacific open-waters (Castillo-Vargasmachuca et al 2012). As part of its culture practices, the determination of effective prophylactic protocols represents a very important aspect, especially when fish are caught in the wild and transported to laboratory conditions (Hadfield and Clayton 2011). Normally, wild Lutjanus peru juvenile are collected using different fishing methods such as gillnet, seine and trawling nets. The use of these methods can cause injury to the fish, and if the lesions are not well treated, further infections may occur (Cubero and Molinero 1997). The use of commercial broad-spectrum disinfectants is a useful resource for prophylactic treatments in commercially cultured species. However, more research is still needed to determine the 
effectiveness of particular substances in each species and its real potential negative effects. This process involves experimenting with different chemicals and techniques to find out the most effective method to minimize the stress (Schelkle et al 2009). Additionally, it is necessary to determine the optimum dose of substance since it may vary depending on the water quality and the severity of the pathogen being treated.

The Yucca schidigera extract have been used as a feed additive to reduce ammonia and fecal odors in animal excreta (Cheeke 2000). It has been proved that this substance can reduce ammonia buildup produced by biogenic sources, hydrogen sulfide and other compounds affecting fish health in both fresh and seawater recirculating aquaculture systems (Kelly and Kohler 2003, Santacruz-Reyes and Chien 2010).

The objective of this study was to determine the effect of natural liquid extract of $Y$. schidigera on water quality and prevent mortality during transfer of the Pacific red snapper $L$. peru from wild to laboratory conditions.

\section{MATERIAL AND METHODS}

The test was conducted in the laboratory of Coastal Bioengineering, at the National School of Fisheries Engineering (Autonomous University of Nayarit). Two hundred wild red snapper juvenile were captured. The capture site $\left(21^{\circ} 10^{\prime} 00.74^{\prime \prime} \mathrm{N}, 105^{\circ} 14^{\prime} 29.95^{\prime \prime} \mathrm{W}\right)$ is known for the abundant occurrence of populations of this species. For their capture, the fishing method used was hand-line due the presence of a rocky-sandy bottom. The fish were transported to the laboratory in a $750 \mathrm{~L}$ plastic tank with similar water conditions to the capture site $\left(24^{\circ} \mathrm{C}\right.$ and 35 $\mathrm{g} \mathrm{L}^{-1}$ water conditions). During transport, aeration was provided with a 12 watts air pump (Hagen $\circledast$ ) and diffuser stones ( $2.5 \mathrm{~cm}$ length). Upon arrival to the laboratory, fish were submerged in a freshwater bath for $5 \mathrm{~min}$ to abate the presence of external parasites. A total of 43 fish were randomly selected and weighted to estimate the overall average weight $(82.0 \pm 4.0 \mathrm{~g})$. The wet weight was measured with an electronic balance and recorded to the nearest $0.1 \mathrm{~g}$.

An experimental design of $3 \times 4$ (three treatments and four repetitions) was carried out. Three water recirculating systems consisting of four $90 \mathrm{~L}$ tanks each, were employed. A total of 144 fish were randomly allotted and placed in the twelve tanks, with twelve fish for each tank. The stocking density per tank was adjusted at $10.9 \mathrm{~kg} \mathrm{~m}^{-3}$. Three groups were tested using a commercial natural concentrated liquid extract of $Y$. schidigera at low concentration $\left(\mathrm{Y}_{\text {low }}\right)$ of 0.25 $\mathrm{mg} \mathrm{L}^{-1}$, a high concentration $\left(\mathrm{Y}_{\text {high }}\right)$ of $0.75 \mathrm{mg} \mathrm{L}^{-1}$, and a control group $(\mathrm{Cg})$ without $Y$. schidigera extract. The extract was administered every $72 \mathrm{~h}$. The bottom of each tank was siphoned daily to remove feces and uneaten feed. During 28 days of the test, fish were fed ad libitum with pieces of raw squid (10:00; 13:00 and 16:00 $\mathrm{h}$ ). The squid was used as food because it has been identified as one of the main feed sources of $L$. peru. Photoperiod was adjusted at 12:12 (L:D lights on $0800 \mathrm{~h}$, lights off $2000 \mathrm{~h}$ ) using a digital timer. Light was provided with one cool white 35 W light tube (General Electric Company $\left.{ }^{\circledR}\right)$. Temperature, salinity and dissolved oxygen were measured with an oxymeter (YSI-85), and a digital pH meter (SevenEasy, model SK-20) was used to measure $\mathrm{pH}$. All parameters were recorded daily. Ammonia nitrogen $\left(\mathrm{N}-\mathrm{NH}_{4}\right)$, nitrite $\left(\mathrm{N}-\mathrm{NO}_{2}\right)$ and nitrate $\left(\mathrm{N}-\mathrm{NO}_{3}\right)$ were measured every 72 hours with a portable photometer (YSI Models 9000). Survival percentage among treatments was compared with ANOVA $(\mathrm{P}<0.05)$. Analyses were performed using STATISTICA 10.0 (Statsoft, Inc. Tulsa, Ok. USA) and Excel 2007 applications.

\section{RESULTS AND DISCUSSION}

This study shows that $Y$. schidigera extract reduced the $\mathrm{N}^{-\mathrm{NH}_{4}}$ levels in the culture water performing the acclimation of the Pacific red snapper juvenile (table 1). Ammonia reduction was higher at maximum extract concentration $Y_{\text {high }}$. Nitrites and nitrates also decreased significantly $(\mathrm{P}<0.05)$ when increasing concentration of $Y$. schidigera extract. The water oxygen concentration rises significantly $(\mathrm{P}<0.05)$ at the maximum of extract concentration. The survival for the $\mathrm{Y}_{\text {high }}$ group was significantly higher $(\mathrm{P}<0.05)$ compared among the treatments and showed a decreasing trend when yucca's extract was reduced. These results suggested that yucca extract performed satisfactorily as a prophylactic treatment for wild L. peru juvenile.

It is known that Yucca saponins have steroids lopophylic nucleus and one or more water-soluble carbohydrate side chains and for that reason, it is used as a feed additive to reduce ammonia and fecal odors in animal excreta, showing beneficial properties in animal production (Cheeke 2000). The Yucca extract capacity to reduce the $\mathrm{NH}_{4}$ has been documented in freshwater and seawater fish (Tidwell et al 1992, Santacruz-Reyes and Chien 2010). Our results demonstrated that $Y$. schidigera extract efficacy could vary with initial $\mathrm{NH}_{4}$ and extract concentrations, elapsed time, as well as their interactions. However, to establish a formal protocol for determining the best preventive treatment, it is necessary to compare chemicals and doses, and either the identification of pathogens present in fish under experimentation, or to induce a controlled infection by specific pathogens to observe the negative, positive or null effect of each chemical on fish under culture conditions (Blaylock et al 2001). Despite the high fish density used in the present study, which was approximately twice of the stocking density compared with those reported by GarciaGarcia et al (2002), there were no negative symptoms or high mortalities in the yucca's treatments. It is possible to conclude that $Y$. schidigera extract effectively improve the water quality and prevent the proliferation of pathogens in red snapper juvenile. 
Table 1. Water quality parameters and survival (mean \pm standard deviation) of red snapper Lutjanus peru, during acclimatization at different yucca extract concentrations.

Calidad del agua y supervivencia del pargo Lutjanus peru durante la aclimatación en diferentes concentraciones de extracto de yuca.

\begin{tabular}{|c|c|c|c|c|c|c|c|c|}
\hline Treatments & $\begin{array}{c}\text { Ye } \\
\text { concentration } \\
\left(\mathrm{mg} \mathrm{L}^{-1}\right)\end{array}$ & $\begin{array}{c}\text { Initial } \\
\mathrm{NH}_{4} \\
\left(\mathrm{mg} \mathrm{L}^{-1}\right)\end{array}$ & $\begin{array}{c}\text { Final } \\
\mathrm{NH}_{4} \\
\left(\mathrm{mg} \mathrm{L}^{-1}\right)\end{array}$ & $\begin{array}{c}\mathrm{N}-\mathrm{NO}_{2} \\
\left(\mathrm{mg} \mathrm{L}^{-1}\right)\end{array}$ & $\begin{array}{c}\mathrm{N}-\mathrm{NO}_{3} \\
\left(\mathrm{mg} \mathrm{L}^{-1}\right)\end{array}$ & $\mathrm{pH}$ & $\begin{array}{l}\text { Dissolved } \\
\text { Oxygen } \\
\left(\mathrm{mg} \mathrm{L}^{-1}\right)\end{array}$ & $\begin{array}{c}\text { Survival } \\
(\%)\end{array}$ \\
\hline $\mathrm{Cg}$ & 0.00 & $0.82 \mathrm{a} \pm 0.03$ & $0.90 \mathrm{a} \pm 0.05$ & $0.29 a \pm 0.02$ & $6.00 \mathrm{a} \pm 0.12$ & $7,50 \mathrm{a} \pm 0.34$ & $6.50 \mathrm{a} \pm 0.41$ & $66.7 \mathrm{a} \pm 15.0$ \\
\hline$Y_{\text {low }}$ & 0.25 & $0.80 \mathrm{a} \pm 0.02$ & $0.48 b \pm 0.03$ & $0.20 \mathrm{~b} \pm 0.05$ & $4.60 \mathrm{~b} \pm 0.20$ & $7,80 \mathrm{a} \pm 0.18$ & $6.80 \mathrm{a} \pm 0.39$ & $91.6 \mathrm{~b} \pm 23.0$ \\
\hline$Y_{\text {high }}$ & 0.75 & $0.79 a \pm 0.03$ & $0.30 \mathrm{c} \pm 0.04$ & $0.18 b \pm 0.03$ & $3.40 \mathrm{c} \pm 0.15$ & $8,00 \mathrm{~b} \pm 0.11$ & $7.30 \mathrm{~b} \pm 0.17$ & $100.0 \mathrm{c} \pm 11.0$ \\
\hline
\end{tabular}

$\mathrm{Cg}=$ control group without $Y$. schidigera extract; $\mathrm{Y}_{\text {low }}=Y$. schidigera at low concentration of $0.25 \mathrm{mg} \mathrm{L}^{-1} ; \mathrm{Y}_{\text {high }}=Y$. schidigera at high concentration of $0.75 \mathrm{mg} \mathrm{L}^{-1}$.

Values in the same column with different superscript letters are significantly different (Tukey's test; $\mathrm{P}<0.05$ ).

It was proved that $Y$. schidigera extract could be effectively reducing ammonia coming from biogenic source (excretion of fish juveniles) and diminishing the mortality of Pacific red snapper juvenile during acclimatization in water recirculating systems. It is recommended the use of yucca extract concentration at a dose of $0.75 \mathrm{mg} \mathrm{L}^{-1}$ to reduce ammonia concentration in marine water for holding red snapper juvenile at a density up to $10.9 \mathrm{~kg} \mathrm{~m}^{-3}$ under the culture conditions exhibited in this study. Furthermore, this represents the first report in demonstrating that $Y$. schidigera extract can be effective to reduce mortality in the Pacific red snapper juvenile in mariculture systems, hence opens the possibilities for more potential applications of $Y$. schidigera extract.

\section{REFERENCES}

Blaylock RB, RM Overstreet, JM Lotz. 2001. Health management in red snapper (Lutjanus campechanus) culture. Bull Natl Res Inst Aquac 5, 5-9.

Castillo-Vargasmachuca S, JT Ponce-Palafox, M García-Ulloa, JL Arredondo-Figueroa, A Ruiz-Luna, EA Chavez, AG Tacon. 2012. Effect of stocking density on growth performance and yield of subadult Pacific Red Snapper cultured in floating sea cages. $N \mathrm{Am}$ $J$ Aquacult 74, 413-418.

Cheeke RP. 2000. Actual and potential applications of Yucca schidigera and Quillaja saponaria in human and animal nutrition. J Anim Sci 77, 1-10.
CONAPESCA, Comisión Nacional de Pesca y Acuacultura. 2012. Carta Nacional Pesquera. Mazatlán, Sinaloa, México.

Cubero L, A Molinero. 1997. Handling, confinement and anesthetic exposure induces changes in the blood and tissue immune characteristics of gilthead sea bream. Dis Aquat Organ 31, 89-94.

Díaz-Uribe JG, EA Chavez, JF Elorduy-Garay. 2004. Evaluación de la pesquería del huachinango (Lutjanus peru) en el suroeste del Golfo de California. Cienc Mar 164, 561-574.

García-García J, A Rouco-Yanez, B Garcia-Garcia. 2002. Directrices generales de diseño de explotaciones de engorde de especies acuícolas en jaulas en mar. Arch Zootec 51, 469-472.

Hadfield CA, LA Clayton. 2011. Fish Quarantine: Current Practices in Public Zoos and Aquaria. J Zoo Wildl Med 42, 641-650.

Kelly AM, C Kohler. 2003. Effects of Yucca shidigera extract on growth, nitrogen retention, ammonia excretion, and toxicity in Channel Catfish Ictalurus punctatus and Hybrid Tilapia Oreochromis mossambicus X O. niloticus. J World Aquacult Soc 34, 156-161.

Rojas MJ, E Maravilla, F Chicas. 2004. Hábitos alimentarios del pargo de la mancha, Lutjanus guttatus (Pisces: Lutjanidae) en Los Cóbanos y Puerto La Libertad, El Salvador. Rev Biol Trop 52, 23-30.

Santacruz-Reyes RA, YH Chien. 2010. Yucca schidigera extract - A bioresource for the reduction of ammonia from mariculture. Bioresour Technol 101, 5652-5657.

Schelkle B, AP Shinn, E Peeler, J Cable. 2009. Treatment of gyrodactylid infections in fish. Dis Aquat Organ 86, 65-75.

Tidwell JH, CD Webster, JA Clark, DH Yancey. 1992. Effects of Yucca shidigera extract on water quality and fish growth in recirculatingwater aquaculture systems. Prog Fish-Cult 54, 196-201. 
